\title{
POTENSI PENURUNAN EMISI GAS RUMAH KACA PADA PENGELOLAAN KOTORAN HEWAN SAPI MELALUI PEMBERIAN PAKAN TAMBAHAN
}

\author{
Ali Pramono \\ Balai Penelitian Lingkungan Pertanian \\ Jl. Raya Jakenan-Jaken Km 5 Pati kode pos 57123 Jawa Tengah \\ Korespondensi Email : ali_pramona@yahoo.com
}

Diterima : 12 Juli 2016 Disetujui : 13 November 2016

\section{Intisari}

Pada sistem integrasi tanaman dan ternak, limbah biomasa digunakan sebagai sumber pakan ternak. Kualitas pakan yang rendah dapat meningkatkan emisi gas rumah kaca (GRK). Oleh karena itu, untuk mengurangi emisi sektor perternakan maka meningkatkan kualitas pakan ternak.Tujuan penelitian untuk mendapatkan informasi pengaruh pemberian pakan tambahan (Silase, Jerami Amoniasi dan UMMB) terhadap emisi gas rumah kaca dari kotoran hewan sapi pada sistem integrasi tanaman dan ternak.Penelitian dilaksanakan di Kebun Percobaan Balai Penelitian Lingkungan Pertanian (Balingtan), Pati pada bulan Mei-Juli 2014. Metode penelitian yang digunakan untuk mengukur emisi GRK adalah sungkup tertutup (Close chamber method), dengan interval 10 menit. Sampel gas $\mathrm{CO}_{2}, \mathrm{CH}_{4}$ dan $\mathrm{N}_{2} \mathrm{O}$ dianalisis menggunakan kromatografi gas. Hasil penelitian menunjukkan bahwa perlakuan pemberian pakan konvensional dan pakan tambahan pada ternak sapi mampu mengurangi emisi GRK sebesar $19 \%$ dibandingkan dengan pemberian pakan konvensional. Emisi GRK dari kotoran hewan sapi yang diberi pakan konvensional sebesar 9,13 $\mathrm{kg} \mathrm{CO}_{2}$-e/ekor/tahun, sedangkan dengan pakan konvensional ditambah pakan tambahan sebesar 7,39 $\mathrm{kg} \mathrm{CO}_{2}$-e/ekor/tahun.

Kata Kunci : Emisi Gas Rumah Kaca, Kotoran Hewan Sapi, Silase

\begin{abstract}
On the integration of crop-livestock systems, waste biomass is used as feed for livestock. Low feed quality may increase emissions of greenhouse gases $(G H G)$. Therefore, to reduce emissions from livestock sector is to improve the quality of animal feed. The purpose of this study was to obtain additional information about the effect of feeding (silage, hay ammoniation and UMMB) against greenhouse gas emissions from cattle manure in crop-livestock integration system. The experiment was conducted at the experimental field of Indonesia Agricultural Environment Research Institute (IAERI/Balingtan), Pati in May-July 2014. The method used to measure the GHG emissions is close chamber method, with an interval of 10 minutes. Samples of $\mathrm{CO}_{2}, \mathrm{CH}_{4}$ and $\mathrm{N}_{2} \mathrm{O}$ were analyzed using gas chromatography. The results showed thattreatment of conventional feeding + feed supplement could reduce GHG emissions as $19 \%$ compared to a conventional feeding. GHG emissions from animal manure fed conventional feed of $9.13 \mathrm{~kg} / \mathrm{head} / \mathrm{year}$, whereas with conventional feed + additional feed of $7.39 \mathrm{~kg} / \mathrm{head} /$ year.
\end{abstract}

Key words : Cattle Manure, Greenhouse Gas Emission, Silage.

\section{PENDAHULUAN}

Salah satu sumber penghasil gas $\mathrm{CH}_{4}$ adalah ternak ruminansia, baik dari proses fermentasi rumen enterik maupun proses degradasi bahan organik kotoran ternak. $\mathrm{CH}_{4}$ dihasilkan oleh hewan herbivora dalam proses pencernaannya melakukan pemecahan karbohidrat oleh mikroorganisme, dimana jumlah gas $\mathrm{CH}_{4}$ yang dilepaskan oleh ternak bergantung pada jenis, umur, berat, kualitas dan kuantitas 
pakan yang diberikan. Berdasarkan jenis ternak, sumber emisi gas $\mathrm{CH}_{4}$ dibedakan menjadi ternak ruminansia, non ruminansia dan unggas. Ternak ruminansia dan non ruminansia mengemisikan gas $\mathrm{CH}_{4}$ dari akibat pencemaran dan pengelolaan kotoran, sedangkan ternak unggas mengemisikan gas $\mathrm{CH}_{4}$ hanya dari aktivitas pengelolaan kotoran. Potensi emisi GRK dari aktivitas peternakan dari satu ekor sapi perah mengeluarkan emisi gas $\mathrm{CH}_{4}$ sebesar $56 \mathrm{~kg} \mathrm{CH}_{4}$ / ekor / tahun, sedangkan sapi pedaging sebanyak $44 \mathrm{~kg}$, kerbau $55 \mathrm{~kg}$, kambing $8 \mathrm{~kg}$, domba $5 \mathrm{~kg}$, kuda $18 \mathrm{~kg}$, unggas / ayam $0 \mathrm{~kg}$ (IPCC, 1994). Emisi $\mathrm{CH}_{4}$ dari pengelolaan kotoran ternak masing-masing: sapi perah 27 , sapi pedaging 2, babi 7, kerbau 3, kambing 0,37, domba 0,23, kuda 2,77, unggas (ayam dan bebek) $0,157 \mathrm{~kg} \mathrm{CH}_{4} /$ ekor / tahun. Data ini berdasarkan asumsi bahwa kotoran ternak tersebut dikelola dengan cara dikeringkan (dry system) (IPCC, 1994).

Pada budidaya tanaman pangan (padi dan jagung) dihasilkan limbah tanaman berupa jerami. Limbah tanaman tersebut dapat dijadikan pakan atau dikomposkan, untuk mengatasi keterbatasan hijauan pakan pada musim kemarau. Limbah tersebut biasanya dikeringkan dan dimanfaatkan untuk memenuhi kekurangan pakan, namun kualitas pakan tergolong rendah. Kualitas pakan dan jerami dapat ditingkatkan dengan cara fermentasi. Jika semua potensi hijauan pakan dimanfaatkan secara maksimal, maka produktivitas dan kapasitas produksi ternak sapi dapat ditingkatkan untuk mengurangi kebutuhan impor daging.

Untuk mengurangi emisi gas $\mathrm{CH}_{4}$ dari ternak perlu diterapkan strategi pemberian pakan yang lebih efisien. Dalam rangka mengurangi dampak pemanasan global, diperlukan upaya inventarisasi dan mitigasi. Inventarisasi dilakukan untuk mengetahui sumber emisi gas rumah kaca serta besar emisi yang dihasilkan. Mitigasi dilakukan untuk memperoleh level emisi tertentu dengan mengganti teknologi yang sudah ada dengan teknologi yang baru.Teknologi mitigasi untuk menurunkan emisi dari perternakan melalui pengembangan kualitas pakan ternak (Silase dan Jerami Amoniasi), penggunaan Urea Molasse Multinutrient Block
(UMMB), program pembiakan jangka panjang, dan pengembangan biogas dari limbah ternak. Implementasi keempat skenario mitigasi tersebut dapat menurunkan emisi sehingga $12,5 \%$ pada tahun 2030. Di Indonesia, emisi $\mathrm{CH}_{4}$ per unit pakan atau laju konversi $\mathrm{CH}_{4}$ lebih besar karena hijauan pakan yang diberikan berkualitas rendah. Semakin tinggi jumlah pemberian pakan berkualitas rendah maka semakin tinggi produksi $\mathrm{CH}_{4}$ (Suryahadi et al., 2002).

Tujuan penelitian untuk mendapatkan informasi pengaruh pemberian pakan tambahan terhadap emisi gas rumah kaca (GRK) dari kotoran hewan sapi pada sistem integrasi tanaman dan ternak.

\section{METODE PENELITIAN}

\section{Alat dan Bahan Penelitian}

Alat yang digunakan dalam yakni, sungkup pengambil gas berbentuk tabung, jarum suntik berukuran $25 \mathrm{ml}$, vial, kromatografi gas. Bahan yang diperlukan antara lain pakan jerami, silase, UMMB, gas $\mathrm{N}_{2}, \mathrm{H}_{2}$, udara tekan, gas standard $\mathrm{CH}_{4}$, $\mathrm{N}_{2} \mathrm{O}$ dan $\mathrm{CO}_{2}$.

\section{Metode Penelitian}

Penelitian menggunakan 15 ekor sapi dengan berat rata-rata $250-300 \mathrm{~kg}$, yang pengelompokannya berdasarkan pada pemberian pakan. Perlakuan yang diberikan adalah 1) pemberian pakan konvensional (jerami, ampas ketela dedak dan konsentrat) dan 2) pemberian pakan konvensional dan pakan tambahan (silase, jerami fermentasi dan UMMB). Parameter yang diamati adalah emisi $\mathrm{CO}_{2}, \mathrm{CH}_{4}$ dan $\mathrm{N}_{2} \mathrm{O}$ setiap minggu. Pengambilan sampel GRK dilakukan secara manual menggunakan paralon berdiameter $21 \mathrm{~cm}$ dan tinggi $30 \mathrm{~cm}$. Sampel diambil menggunakan jarum suntik volume $25 \mathrm{ml}$ dengan interval waktu pengambilan setiap menit ke-10, 20, 30, 40 dan 50 . Sampel diambil sebanyak $20 \mathrm{ml}$ dan dimasukkan ke dalam vial berukuran $10 \mathrm{ml}$. Sampel gas $\mathrm{CO}_{2}, \mathrm{CH}_{4}$ dan $\mathrm{N}_{2} \mathrm{O}$ dianalisis menggunakan gas Chromatografi (GC) tipe GHG-450 Varian. Hasil analisa sampel gas dihitung menjadi $\square$ uks dan emisi GRK menggunakan rumus sebagai berikut (IAEA, 1993). 


$$
\mathrm{E}=\mathrm{X} \frac{\mathrm{dc}}{\mathrm{dt}} \quad \frac{\mathrm{Vch}}{\mathrm{Ach}} \times \frac{\mathrm{mW}}{\mathrm{mV}} \times \frac{273,2}{(273,2+\mathrm{T})}
$$

Keterangan :

E : Emisi gas $\mathrm{CH}_{4} / \mathrm{CO} / 2 / \mathrm{NO}_{2}\left(\mathrm{mg} / \mathrm{m}^{2} /\right.$ hari)

dc/dt : Perbedaan konsentrasi $\mathrm{CH}_{4} / \mathrm{CO}_{2} / \mathrm{N}_{2} \mathrm{O}$ per waktu (ppm/menit)

Vch : Volume boks $\left(\mathrm{m}^{3}\right)$

Ach : Luas boks $\left(\mathrm{m}^{2}\right)$

$\mathrm{mW}$ : Berat molekul $\mathrm{CH}_{4} / \mathrm{CO}_{2} / \mathrm{N}_{2} \mathrm{O}(\mathrm{g})$

$\mathrm{mV}$ : Volume molekul $\mathrm{CH}_{4} / \mathrm{CO}_{2} / \mathrm{N}_{2} \mathrm{O}(22,41 \mathrm{l})$

$\mathrm{T}$ : Temperatur rata-rata selama pengambilan contoh gas $\left({ }^{\circ} \mathrm{C}\right)$

\section{HASIL DAN PEMBAHASAN}

Dalam sistem integrasi tanaman dan ternak, kebutuhan pakan sapi dapat dipenuhi dari jerami hasil budidaya padi. Jerami tidak dibakar karena akan menambah jumlah karbon di atmosfer. Hasil sekuestrasi karbon dari atmosfer melalui fotosintesis tanaman padi disimpan dalam gabah dan biomasa tanaman. Apabila biomasa digunakan untuk pakan ternak, maka akan mengurangi emisi GRK yang diakibatkan oleh pembakara dan pengomposan jerami. Jerami segar dapat langsung digunakan untuk pakan. Jerami merupakan sumber pakan karena kandungan selulosa yang tinggi, namun perlu ditingkatkan daya cernanya dan kandungan gizinya untuk menambah efisiensi dan mengurangi emisi GRK dari fermentasi enterik dan kotoran hewan. Jerami dapat dikeringkan terlebih dahulu dan disimpan untuk pakan ternak dalam jangka waktu tertentu. Jerami dapat juga diolah menjadi silase dan jerami amoniasi untuk meningkatkan nilai gizi dan daya simpan pakan. Bila nilai gizi pakan meningkat, maka proses pencernaan rumen akan lebih sempurna karena sumber karbon yang tersedia dapat dimanfaatkan untuk pembentukan biomolekul dalam tubuh ternak dan hanya sedikit yang terombak menjadi asam organik dan gas. Di Kebun Percobaan
Balingtan, pemberian silase, jerami amoniasi dan Urea molasses multinutrient block (UMMB) (Gambar 1) dilakukan untuk meningkatkan bobot badan sapi sekaligus menurunkan emisi GRK.
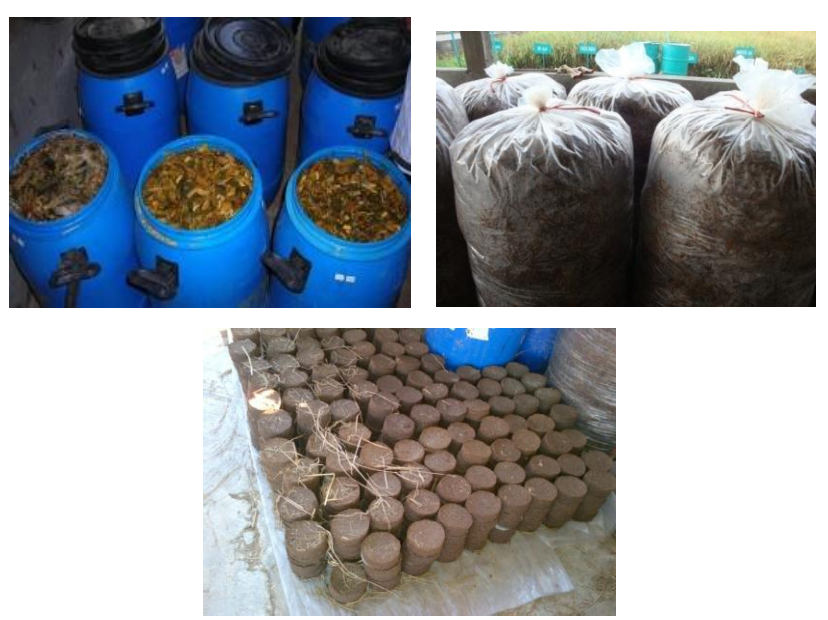

Gambar 1. Silase, Jerami Amoniasi dan UMMB

(kiri, tengah dan kanan)

Pengambilan sampel GRK menggunakan metode sungkup tertutup, seperti pada Gambar 2. Konsentrasi gas diukur dengan menggunakan gas kromatogram yang kemudian datanya diolah menjadi fluks dan emisi. Hasil rata-rata pengukuran fluks GRK baik $\mathrm{CO}_{2}, \mathrm{CH}_{4}$ maupun $\mathrm{N}_{2} \mathrm{O}$ pada perlakuan pemberian pakan konvensional + pakan tambahan (Silase, Jerami Amoniasi dan UMMB) menunjukkan nilai yang lebih kecil daripada pemberian pakan konvensional (Tabel 1). Pengukuran fluks $\mathrm{CO}_{2}$ dengan perlakuan pakan konvensional memberikan hasil sebesar $0,9 \mathrm{mg}$ $\mathrm{CO}_{2}$ /gr kohe/hari. Pemberian pakan konvensional dittambah pakan tambahan menghasilkan fluks yang lebih rendah yaitu $0,8 \mathrm{mg} \mathrm{CO}_{2} / \mathrm{gr}$ kohe/hari. Fluks $\mathrm{CH}_{4}$ juga lebih rendah, yaitu dari $0,011 \mathrm{mg}$ $\mathrm{CH}_{4}$ /gr kohe/hari dengan pakan konvensional dan 0,008 $\mathrm{mg} \mathrm{CH}_{4} / \mathrm{gr}$ kohe/hari dengan pakan konvensional + pakan tambahan. Demikian juga fluks $\mathrm{N}$ O,dengan pakan konvensional 0,2 $\mu \mathrm{g} \mathrm{NO} /$

gr kohe/hari sedangkan dengan pakan konvensional + pakan tambahan sebesar $0,039 \mu \mathrm{g} \mathrm{N}_{2} \mathrm{O} /$ gr kohe/ hari. 


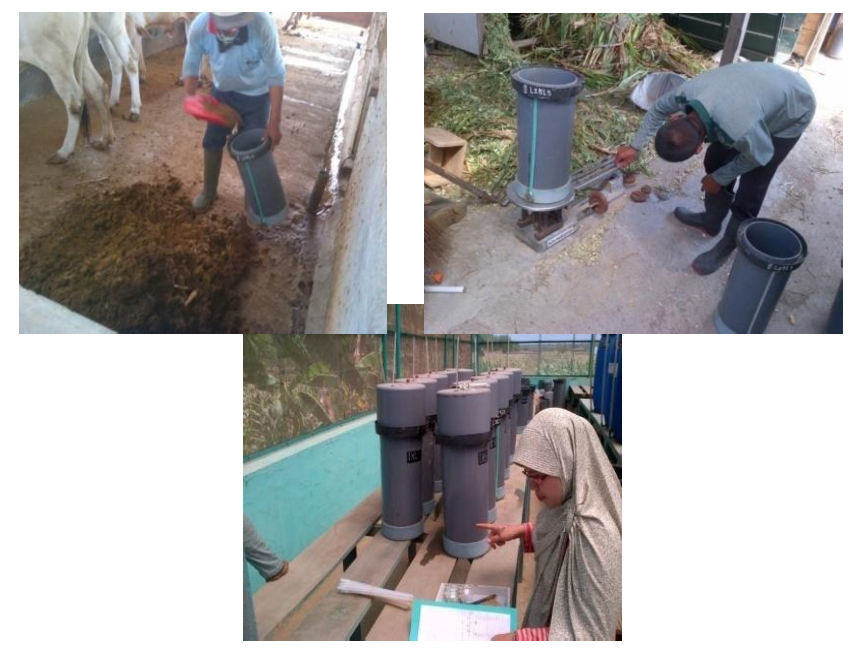

Gambar 2. Pengambilan Sampel GRK dengan Metode Sungkup Tertutup (Kiri, Tengah dan Kanan)

Pengolahan, penyimpanan, dan pengangkutan kotoran sapi dapat mengemisi $\mathrm{CH}_{4}$ dan $\mathrm{N}_{2} \mathrm{O} . \mathrm{CH}_{4}$ dihasilkan dari dekomposisi anaerob. Emisi $\mathrm{N}_{2} \mathrm{O}$ dihasilkan melalui jalur langsung maupun tidak langsung. Emisi $\mathrm{N}_{2} \mathrm{O}$ langsung dihasilkan dari bagian siklus $\mathrm{N}$ melalui nitrifikasi dan denitrifikasi $\mathrm{N}$ organik dalam kotoran dan urin sapi. Jalur emisi $\mathrm{N}_{2} \mathrm{O}$ tidak langsung terdiri dari hasil volatilisasi $\mathrm{N}$ (sebagai $\mathrm{NH}_{3}$ dan $\mathrm{NO}_{\mathrm{x}}$ ) dan dari deposisi gas dan produknya $\left(\mathrm{NH}^{+4}\right.$ dan $\mathrm{NO}^{-}$ $\left.{ }^{3}\right)$.

Potensi penurunan emisi GRK dengan pakan konvensional + pakan tambahan pada ternak sapi mencapai $19 \%$ (Tabel 2). Emisi GRK dari kohe sapi yang diberi pakan konvensional bila tidak dilakukan pengelolaan (hanya ditumpuk) sebesar $9,13 \mathrm{~kg} /$ ekor/tahun, sedangkan dengan pakan konvensional + pakan tambahan menghasilkan emisi sebesar 7,39 $\mathrm{kg} / \mathrm{ekor} / \mathrm{tahun}$.
Tabel 2. Potensi Penurunan Emisi GRK dengan Pakan Tambahan

\begin{tabular}{|c|c|c|c|c|}
\hline \multirow[b]{2}{*}{ Parameter } & \multicolumn{2}{|c|}{ Fluks GRK } & \multicolumn{2}{|c|}{$\begin{array}{c}\text { Rata-rata emisi (kg/ } \\
\text { ekor/tahun) }\end{array}$} \\
\hline & K & $\mathrm{K}+\mathrm{PT}$ & $\mathrm{K}$ & $\mathrm{K}+\mathrm{PT}$ \\
\hline $\begin{array}{l}\mathrm{CO}_{2}(\mathrm{mg} / \mathrm{gr} \\
\text { kohe/hari) }\end{array}$ & 0,917 & 0,867 & 7,426 & 7,021 \\
\hline $\begin{array}{l}\mathrm{CH}_{4} \mathrm{mg} / \mathrm{gr} \\
\text { kohe/hari }\end{array}$ & 0,011 & 0,007 & 0,089 & 0,057 \\
\hline $\begin{array}{l}\mathrm{N}_{2} \mathrm{O} \text { (ug/gr } \\
\text { kohe/hari) }\end{array}$ & ก $\mathrm{s} n$ & $\cap \cap 20$ & 0,085 & 0,316 \\
\hline $\mathrm{CO}_{2}-\mathrm{e}$ & & & 9,13 & 7,39 \\
\hline Penurunan $\mathrm{CO}_{2}$-e & & & $19 \%$ & \\
\hline
\end{tabular}

Keterangan: *) Jumlah sapi 15 ekor (5 jantan dan 10 betina); $\mathrm{K}=$ Pakan Konvensional, $\mathrm{K}+\mathrm{PT}=$ Pakan konvensional dan

Hasil pengukuran fluks GRK menunjukkan bahwa pemberian pakan tambahan (silase, UMMB, jerami amoniasi) dapat menurunkan fluks GRK dibandingkan dengan pakan konvensional . Hal ini disebabkan karena pakan tambahan dapat meningkatkan nilai cerna dan efisiensi pemecahan selulosa menjadi glukosa dan sedikit terbentuk asam

organik. Sistem pencernaan rumen bekerja lebih sempurna dengan rasio $\mathrm{C} / \mathrm{N}$ yang seimbang untuk pertumbuhan. Hal ini menyebabkan karbon yang terkandung dalam kohe menurun, sehingga gas rumah kaca yang diemisikan akan lebih rendah.

Pada penelitian ini, inkubasi dilakukan pada kondisi aerob (Gambar 2), dimana proses nitrifikasi 
Tabel 1. Hasil Pengukuran Fluks GRK dari Kotoran Sapi

\begin{tabular}{|c|c|c|c|c|c|c|c|}
\hline \multirow{2}{*}{ Rata-Rata Fluks } & \multicolumn{5}{|c|}{ Ulangan } & \multirow{2}{*}{ Rata-rata } & \multirow{2}{*}{$\mathrm{SD}$} \\
\hline & 1 & 2 & 3 & 4 & 5 & & \\
\hline \multicolumn{8}{|l|}{ Pakan Konvensional*) } \\
\hline $\mathrm{CO}_{2}(\mathrm{mg} / \mathrm{gr} / \mathrm{hari})$ & 0,832 & 1,136 & 0,936 & 0,887 & 0,797 & 0,917 & 0,311 \\
\hline $\mathrm{CH}_{4}$ (mg/gr/hari) & 0,011 & 0,016 & 0,011 & 0,008 & 0,008 & 0,011 & 0,003 \\
\hline $\mathrm{N}_{2} \mathrm{O}(\mu \mathrm{g} / \mathrm{gr} / \mathrm{hari})$ & 0,255 & 0,244 & 0,149 & 0,145 & 0,205 & 0,200 & 0,058 \\
\hline \multicolumn{8}{|c|}{ Pakan konvensional + pakan tambahan**) } \\
\hline $\mathrm{CO}_{2}(\mathrm{mg} / \mathrm{gr} / \mathrm{hari})$ & 0,387 & 1,013 & 1,018 & 0,860 & 1,059 & 0,867 & 0,363 \\
\hline $\mathrm{CH}_{4}(\mathrm{mg} / \mathrm{gr} / \mathrm{hari})$ & 0,004 & 0,005 & 0,004 & 0,006 & 0,017 & 0,007 & 0,000 \\
\hline $\mathrm{N}_{2} \mathrm{O}(\mu \mathrm{g} / \mathrm{gr} / \mathrm{hari})$ & 0,035 & 0,033 & 0,043 & 0,032 & 0,049 & 0,039 & 0,005 \\
\hline \multicolumn{8}{|l|}{ Keterangan: } \\
\hline \multicolumn{8}{|c|}{ *) Pengamatan selama 13 kali } \\
\hline **) Pengamatan sc & & & & & & & \\
\hline
\end{tabular}

terjadi pada kotoran ternak yang disimpan asalkan dapat cukup pasokan oksigen. Nitrikasi tidak terjadi dalam kondisi anaerob, nitrit dan nitrat akan ditransformasikan $\mathrm{ke}_{2} \mathrm{O}$ menjadi dinitrogen $\left(\mathrm{N}_{2}\right)$ selama proses denitrifkasi dengan kondisi anaerobik. Rasio $\mathrm{N}_{2} \mathrm{O}$ akan meningkatkan $\mathrm{N}_{2}$. Secara ringkas, produksi dan emisi $\mathrm{N}_{2} \mathrm{O}$ dari kotoran ternak yang dikelola membutuhkan nitrit maupun nitrat di lingkungan an-aerobik yang didahului oleh nitrifikasi dengan kondisi aerobik untuk pembentukan nitrogen teroksidasi. Selain itu, terdapat kondisi yang mencegah penurunan $\mathrm{N}_{2} \mathrm{O}$ untuk menghasilkan $\mathrm{N}_{2}$, seperti $\mathrm{pH}$ rendah dan uap air yang terbatas.

UMMB merupakan pakan yang mengandung urea sebagai sumber $\mathrm{N}$ dimana dengan penambahan UMMB akan memudahkan tersedianya $\mathrm{N}$ untuk mikroba rumen, molases adalah sumber karbohidrat yang sangat mudah terfermentasi dalam rumen sehingga merupakan sumber energi dan kerangka karbon yang dapat tersedia untuk mensintesis protein. Blok merupakan salah satu bentuk teknologi sederhana yang dikembangkan dengan memadatkan campuran urea molases dan multinutrient untuk pemerasan sehingga dapat dijilat untuk mencegah kosumsi yang berlebihan dalam waktu singkat karena dapat menyebabkan keracunan ternak. Keuntungan pembuatan UMMB adalah mudah dipindahkan (pengangkutan dan penanganan mudah), membutuhkan sedikit ruang penyimpanan, dapat digunakan sebagai "carrier", mudah pemberian kepada ternak, bernilai gizi tinggi (Mide, 2002), meminimumkan bahaya keracunan dan dapat diisi bahan NPN dengan level relatif tinggi (Tangdilintin, 2002). Penggunaan UMMB merupakan salah satu cara untuk meningkatkan kecernaan pakan ternak ruminansia, khususnya pada musim kemarau berkepanjangan. Berbagai laporan hasil uji coba membuktikan bahwa pakan blok dapat meningkatkan produktivitas dan tingkat reproduksi pada ternak ruminansia.

Pemberian pakan tambahan mempunyai berdampak positif terhadap lingkungan, karena dapat menurunkan fluks GRK. Pemberian suplemen berupa UMMB, silase dan jerami amoniasi pada sapi jantan dan betina selama 2 minggu dapat menurunkan fluks dan emisi GRK. Sebesar $19 \%$.

Hal ini disebabkan karena pakan tambahan pakan dapat meningkatkan efisiensi pemecahan selulosa menjadi glukosa. Pakan tambahan UMMB dapat meningkatkan produktivitas maupun reproduksi ternak ruminansia (Qurimanasari, 2011).

\section{KESIMPULAN}

Pemberian pakan konvensional dan pakan tambahan pada ternak sapi mampu mengurangi emisi GRK sebesar $19 \%$ dibandingkan dengan pemberian pakan konvensional. Emisi GRK dari kotoran sapi yang diberi pakan konvensional sebesar 9,13 kg /ekor / tahun, dan pakan konvensional + pakan tambahan sebesar 7,39 kg/ekor/tahun. 


\section{DAFTAR PUSTAKA}

IAEA. 1993.Manual on Measurement of Methane and Nitrous Oxide Emissions from Agricultural, Vienna, Austria.International Atomic Energy Agency.

IPCC.1994. Greenhouse Gas Inventory Workbook: IPCC Guidelines for National Greenhouse Gas Inventories Volume 2, UNEP-WMO.

Mide MZ. 2002. Teknik Pembuatan Urea Molasses Multinutrient Block (UMMB). Makalah Kursus Singkat Penggunaan Teknologi Radio- Immunoassay (RIA) dan Urea Molasses Multinutrient Block (UMMB) dalam Biologi Reproduksi Ternak. Kerjasama Fakultas Peternakan Universitas Hasanuddin dengan Direktorat Jenderal Pendidikan Tinggi, Departemen Pendidikan Nasional, Makassar.

Qurimanasari, E. 2011. Pendugaan Emisi Gas Rumah Kaca Dari Sektor Peternakan Di Provinsi Jawa Barat. Skripsi. Departemen Ilmu Nutrisi Dan Teknologi Pakan Fakultas Peternakan Institut Pertanian Bogor

Suryahadi AR, Nugraha AB \& R Boer. 2002. Laju konversi metan dan faktor emisi metan pada Kerbau yang diberi ragi tape lokal yang berbeda kadarnya yang mengandung Saccharomyces cerevisiae. Ringkasan Seminar Program Pascasarjana, Institut Pertanian Bogor. Bogor.

Tangdilintin,FK.2002.PakanTambahan(Supplement). Makalah Kursus Singkat Penggunaan Teknologi Radioimmunoassay (RIA) dan Urea Molasses Multinutrient Block (UMMB) dalam Biologi Reproduksi Ternak. Kerjasama Fakultas Peternakan Universitas Hasanuddin dengan Direktorat Jenderal Pendidikan Tinggi, Departemen Pendidikan Nasional, Makassar. 